\title{
Atmospheric Pollutants and the Occurrence of Bromeliads in Electric Power Distribution Network
}

\author{
Gleiciane Fernanda de Carvalho Blanc ${ }^{1}$, Bernardo Lipski ${ }^{1}$, Juliano José da Silva Santos ${ }^{1}$, Karime \\ Dawidziak Piazzetta ${ }^{1}$, Juliane de Melo Rodrigues ${ }^{1}$, and Luciana Leal ${ }^{2}$ \\ ${ }^{1}$ Institutos Lactec, Centro Politécnico da UFPR \\ Rodovia BR-116, km 98, n 8813, Curitiba, Paraná, Brasil \\ gleiciane.carvalho@lactec.org.br; bernardo.lipski@lactec.org.br; juliano.santos@lactec.org.br; \\ karime.piazzetta@lactec.org.br; juliane@lactec.org.br \\ ${ }^{2}$ Copel Distribuição S.A. \\ Rua José Izidoro Biazetto, $n^{\circ}$ 158, Curitiba, Paraná, Brasil \\ luciana.leal@copel.com
}

\begin{abstract}
The occurrence of atmospheric bromeliads (Tillandsia spp. - Bromeliaceae) in the structures of electric power distribution networks is a problem for energy concessionaires. A research project is underway to investigate possible factors contributing to bromeliad occurrence in these structures. One stage of the project is to evaluate the correlation between atmospheric pollutants and the occurrence of bromeliads in urban electric network cables using atmospheric dispersion modelling. The results indicate a correlation between pollutants and infestation of bromeliads in regions with higher vehicular than industrial emissions in the study area (Ponta Grossa city, Paraná State, Brazil).
\end{abstract}

Keywords: Air quality, vehicular emissions, Tillandsia, principal component analysis

\section{Introduction}

The study of atmospheric pollution became important for researchers and society with the development of large urban centres and the industrial revolution. Since then, air quality has been changing and impacting population health and the environment. One tool used to investigate pollutant behaviour and control and manage air quality is mathematical modelling of atmospheric pollutant dispersion. Models have been widely used in scientific and engineering projects and are often applied to find solutions to environmental problems [1].

The occurrence of atmospheric bromeliads (Tillandsia spp. - Bromeliaceae) in electric power distribution network structures is a problem for energy concessionaires. The presence of bromeliads provides a negative visual effect and causes the impression of abandonment and lack of asset maintenance. In addition, energy distributors carry the costs for cleaning infested cables and do not have the information to define best maintenance practices nor to understand the impacts caused by this infestation. Situations such as this have already been reported in Brazil - [2] and [3] - and in other countries - [4] and [5]. However, there still has been no in-depth research on the subject.

Studies developed in the city of Curitiba, State of Paraná, Brazil, related the bromeliad occurrence to pollution from vehicular sources - [3] and [6]. A research project in partnership with the local energy concessionaire has been developed with the objective of investigating possible factors that contribute to bromeliad fixation in energy distribution network structures. One stage of this project, presented here, was to evaluate the correlation between atmospheric pollutants and bromeliad occurrence in electric network structures using atmospheric dispersion modelling.

\section{Theoretical Framework}

The presence of atmospheric bromeliads (Tillandsia spp. - Bromeliaceae) in aerial electric power distribution networks has been reported in urban areas of several Brazilian cities and in other countries in the South American continent. Although bromeliads appear to exist harmoniously with energy networks, it is assumed that in addition to visual aspects, 
bromeliads can cause problems related to safety and energy supply quality, as well as hamper the visual inspection of networks, precluding preventive defect verification by maintenance teams [3].

The relationship between species of the genus Tillandsia and energy distribution networks is long known and of wide geographic occurrence, although little studied. Infestations dating back to 1951 in the state of Santa Catarina, Brazil, have been reported [2]. In addition, the establishment and growth of Tillandsia spp. have been studied in Argentina [4], Panama [5], Mexico [7] and Costa Rica [8].

The genus Tillandsia consists of aerial species capable of inhabiting naked rocks, exposed branches or even dead trees and wooden poles. Tillandsia species are usually called weeds and can reach significant degrees of infestation on trees and shrubs in altered environments [9] [10].

Several bromeliad species have been studied as bioindicators of atmospheric pollution, mainly by heavy metals. Some of the studies reported in the literature - [11], [12], [13], [14], [15], [16], [17], [18], [19], [20] and [21] - evaluated Tillandsia species as potential bioindicators of air pollution in several countries, such as Colombia, Argentina, Mexico and Bolivia. In Brazil, there are only a few studies that have reported the use of Tillandsia species as air pollution bioindicators in urban areas - [22], [23], [24], [25] and [6].

Tillandsia recurvata is the most common species present in electric power distribution networks and can be found from Chile to Argentina in South America, to the Caribbean and Central America, reaching Mexico and Southeast North American [6]. In North America and Europe, Tillandsia recurvata is commonly known as "ball moss" although it does not belong to the group of mosses, or bryophytes [3].

Piazzetta [6] presented and summarized the Tillandsia recurvata characteristics that show its potential as an atmospheric pollution bioindicator in urban environments with some degree of air quality alteration (Fig. 1); once the species colonizes several substrates, it obtains water and nutrients directly from the atmosphere. Tillandsia recurvata roots function only for fixation, guaranteeing their independence from soil.

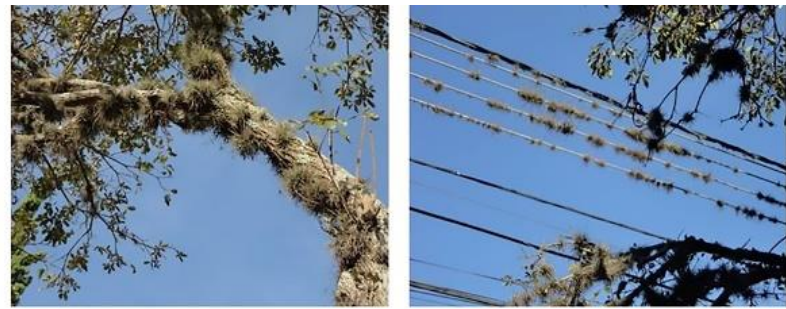

Preferential substrates for the development of Tillandsia recurvata

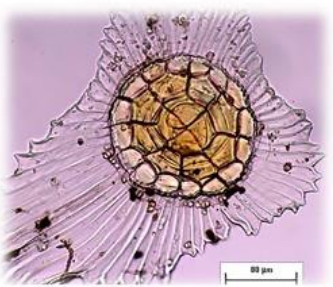

Absorbent trichomes

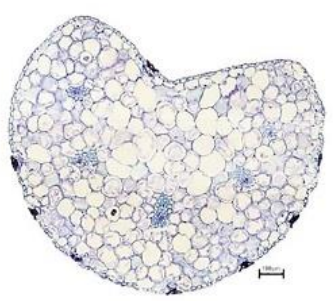

Compact and simple structure

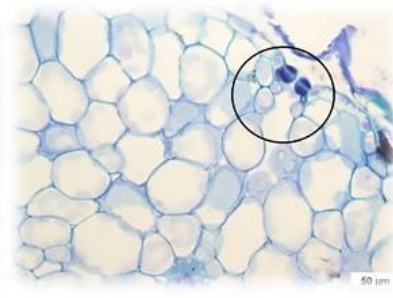

Low stomatal density
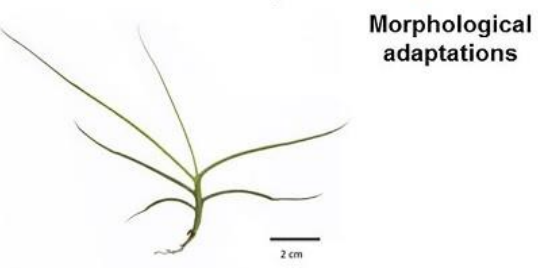

Leaf format

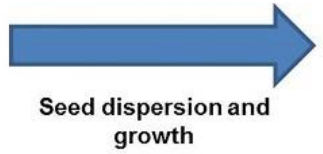

growth

Bioindicator of air quality

Fig. 1: Schematic diagram illustrating T. recurvata characteristics that show potential as an atmospheric pollution bioindicator in urban environments with some degree of air quality alteration (adapted from Piazzetta [6]). 


\section{Methodology}

The AERMOD View 9.1 model was used to simulate the atmospheric pollutant dispersion in the study area.

\subsection{Study Area and Model Data Inputs}

The area defined for the study was the urban area of the city of Ponta Grossa (S2505'42", W50 09'43"), State of Paraná, Brazil (Fig. 2), which presents the highest bromeliad infestation in the state's electric power distribution network.

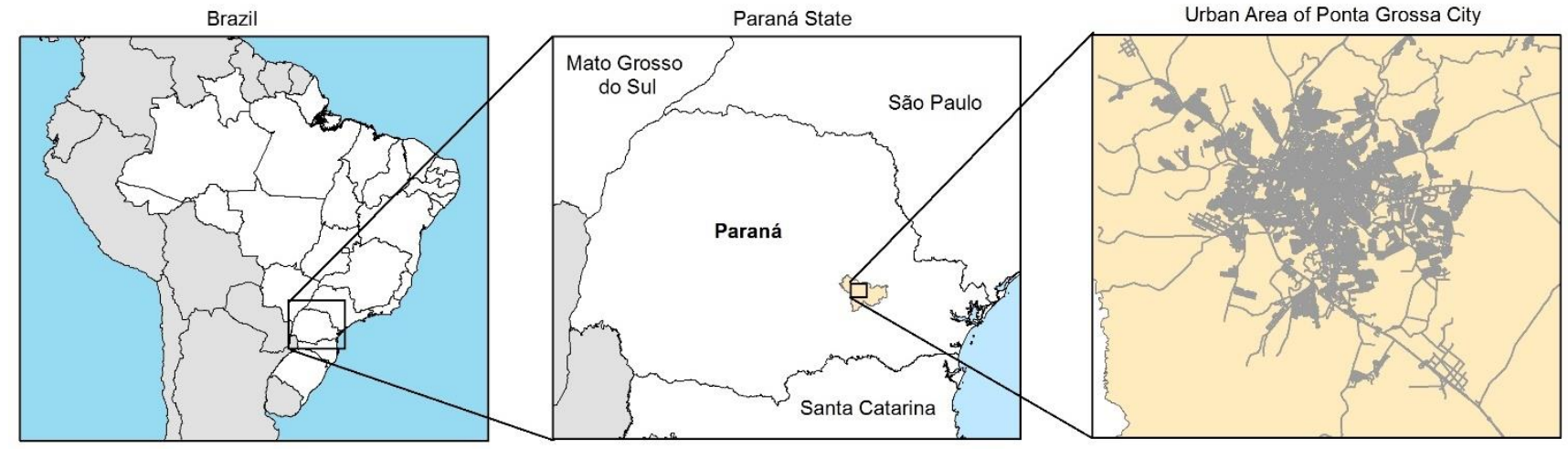

Fig. 2: Study area location.

The AERMOD model requires meteorological, topographic, emission source and receptor data. For meteorological data, five years of hourly data were considered, from January 1, 2010 to December 31, 2014, obtained from an existing automatic meteorological station in the city. The following variables were used: temperature $\left({ }^{\circ} \mathrm{C}\right)$, relative humidity $(\%)$, atmospheric pressure $(\mathrm{hPa})$, radiation $\left(\mathrm{W} / \mathrm{m}^{2}\right)$, precipitation $(\mathrm{mm})$, speed $(\mathrm{m} / \mathrm{s})$ and wind direction. Cloud cover data (in tenths) were obtained from the nearest conventional meteorological station with daily data. It was used the daily cloud clover data for all hours of the day.

Topographic data were obtained from contour curves of the Hydrographic Base of the State of Paraná. Contour curves are at 1:50,000 scale with a resolution of 20 metres. In the modelled area, altitude varies from approximately 770 to 1090 metres.

Eighteen industries were considered as fixed sources of pollutant emissions and twenty-one streets with high vehicle circulation as mobile sources. For each source, emission rates were considered for the following pollutants: nitrogen oxides (NOx), carbon monoxide (CO), sulphur dioxide (SO2), total particulate matter (PM) and total hydrocarbons (HCT).

Simulation of atmospheric dispersion in Ponta Grossa was based on a uniform grid of receptors defined by an area of $430 \mathrm{~km}^{2}, 20.0 \mathrm{~km}$ long and $21.5 \mathrm{~km}$ wide, totalling 1804 receptors spaced every 500 metres horizontally and vertically. Sites with bromeliad infestation in the electric network were identified in the field, totalling 171 discrete receptors, and were used as discrete receptors for pollutant concentration calculations.

\subsection{Field Data}

Between May and June 2016, bromeliad infestation sites were identified in the study area by dividing the city into squares. These sites were georeferenced and bromeliad abundance was evaluated; occupation percentages were determined according to biomass. The higher the biomass, the greater the percentage. The classes considered were: 0 to 10,10 to 30 , 30 to 50,50 to 70 and 70 to $100 \%$.

\subsection{Statistical Analysis}

Principal component analysis was used to evaluate the correlation between field and model results. The data matrix was constructed so that rows represented sites with bromeliad infestation and columns represented the five concentration classes of each pollutant and the classes of bromeliad biomass. 


\section{Results and Discussion}

In the study area, 171 sites were visited and in 99 bromeliads were identified as adhering to electric power distribution network structures. A map with a site infestation index characterizes the percentage of bromeliad biomass occupations (Fig. 3).

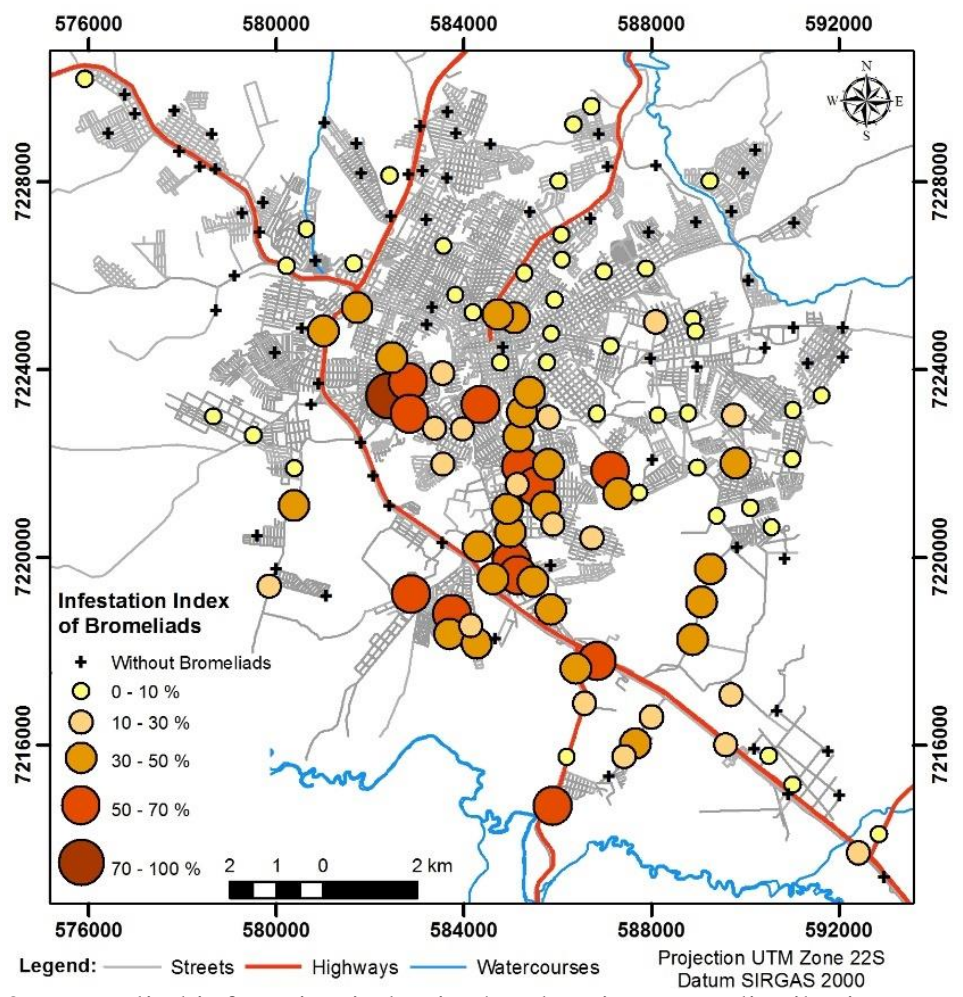

Fig. 3: Bromeliad infestation index in the electric power distribution network.

Pollutant maximum hourly concentrations and average concentrations for the five-year period obtained from modelling the 171 sites are presented in Fig. 4, and the stationary and mobile sources are considered separately.

The highest carbon monoxide concentrations are obtained in the city centre and along the highways and avenues of greater flow, the regions strongly influenced by vehicular emissions. For stationary sources, despite modelling considerations including industries with CO emissions, their contribution is significantly lower (approximately 10\%) than emission contributions from vehicular traffic (approximately 90\%).

For total hydrocarbons, both stationary and mobile emission sources contribute to the simulated concentrations. As shown in Fig. 4, concentrations from fixed sources, mainly metallurgical industries, are concentrated in the area close to their point of emission, while original vehicular emission contributions are evident in central Ponta Grossa where there is a greater flow of vehicles as well as in the areas along highways and avenues with greater flow.

The contribution of stationary sources is also verified in the regions around emission points for the particulate material. Vehicular emissions make no significant contribution to PM concentrations. The concentrations obtained are distributed equally in the central area of the city as well as in the most remote areas and in the regions near the highways. It should be noted that in addition to stationary and mobile sources considered in the modelling, there are diffuse sources, such as resuspension and secondary formation, not addressed in this study, which may explain the low concentrations of this pollutant obtained in the simulations. 
Maximum Hourly Concentration

Stationary Sources

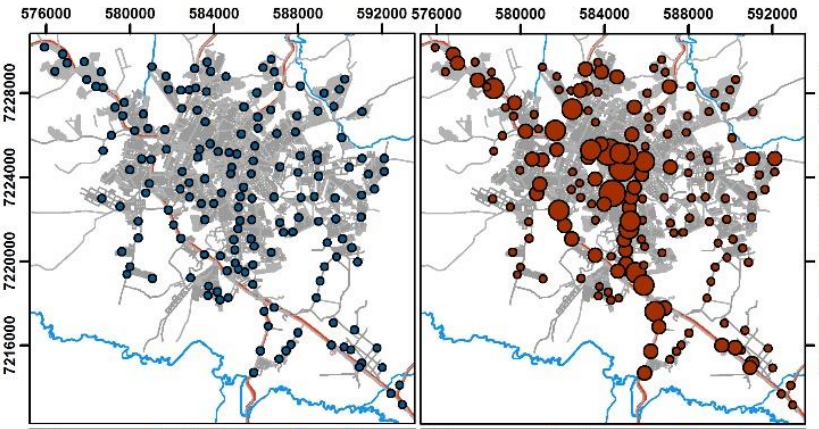

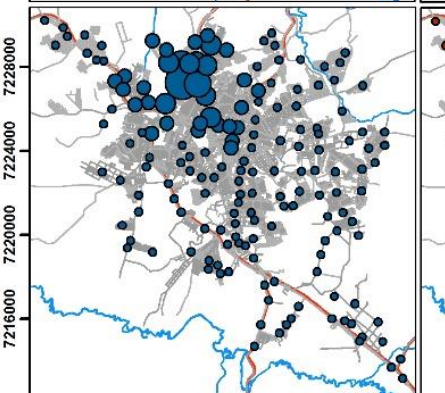

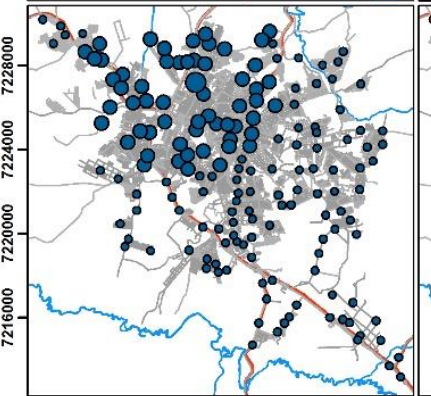

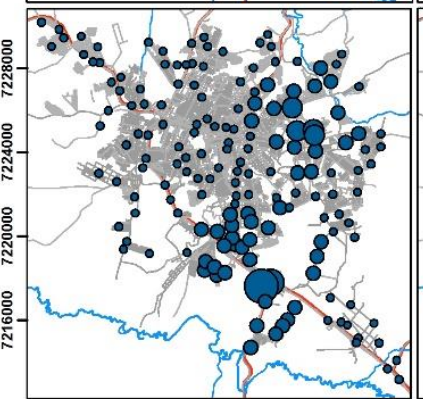
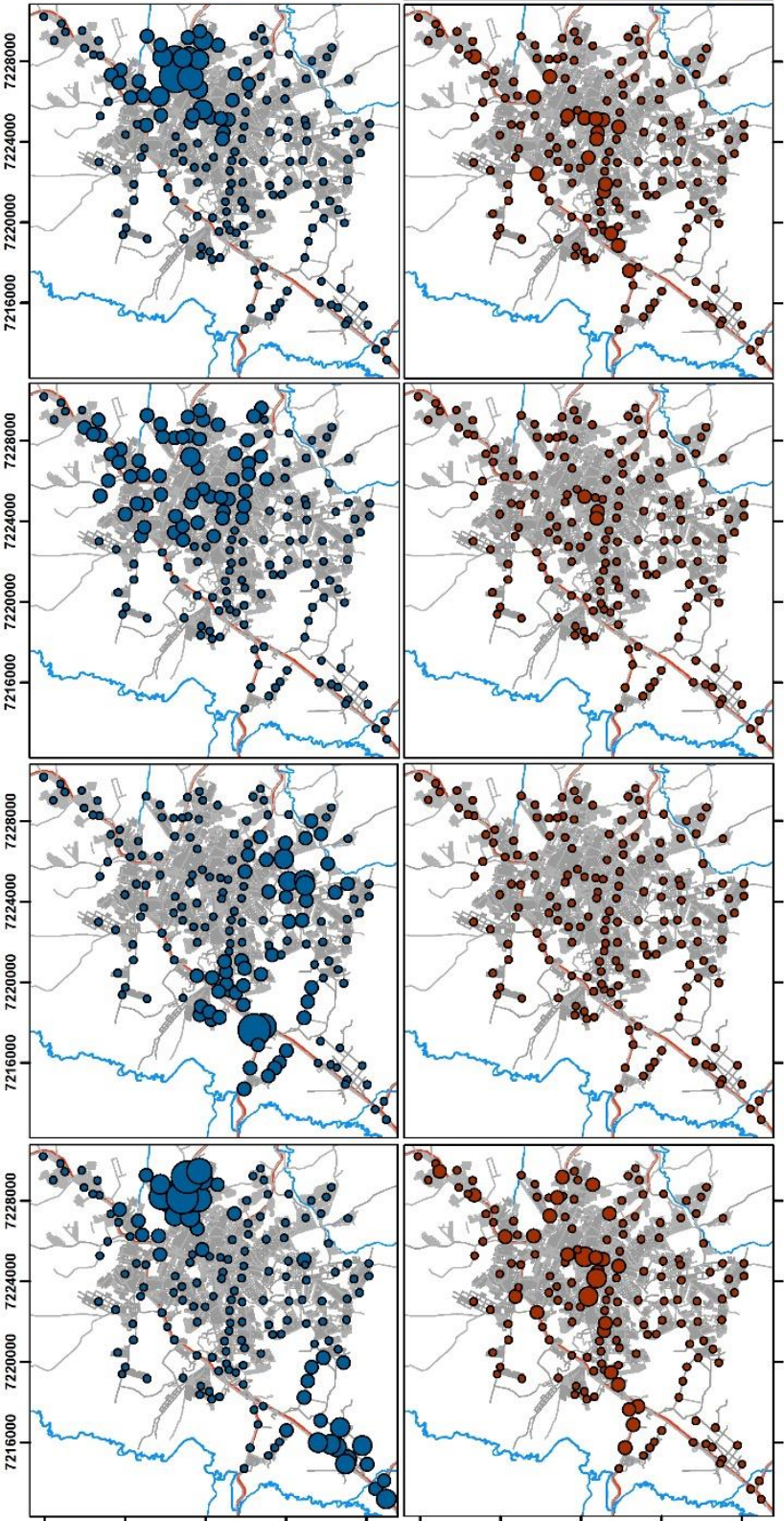

Legend: - Watercourses - Streets - Highway
然)

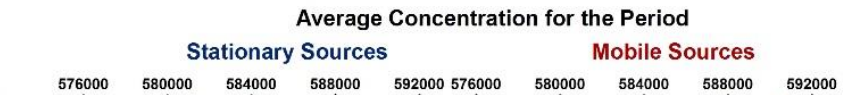

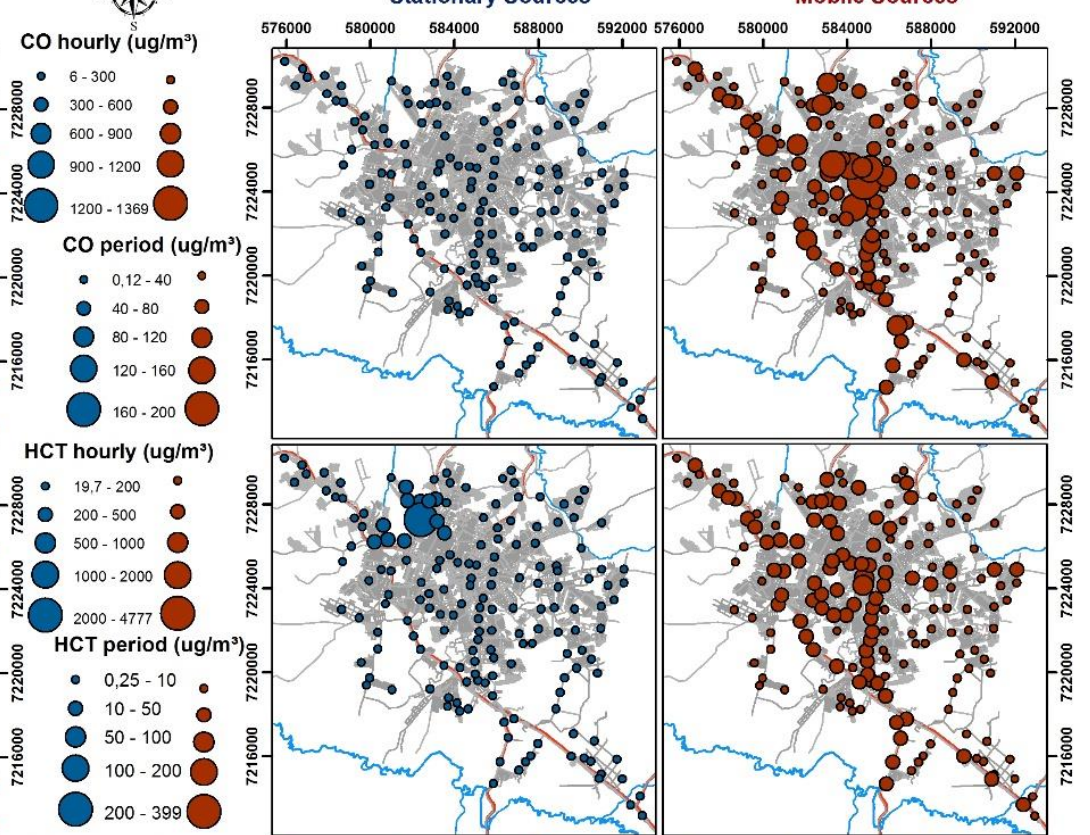

○ $0.75-10$.

$10-100 \quad 0$

$100 \cdot 200$

ㅇํㅇ $200 \cdot 300$

$300-434 \bigcirc$

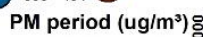

- 0,03-5

- 5 - 10

(10-15

15-20

$20-24,7 \bigcirc$

NOx hourly (ug $/ \mathrm{m}^{3}$ )
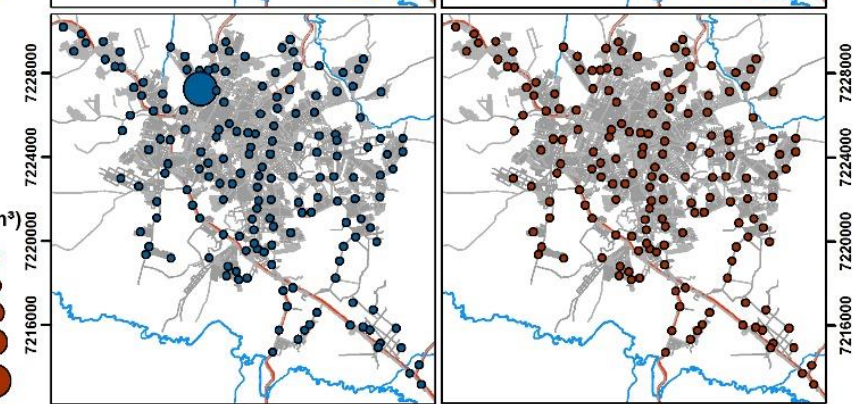

$\begin{array}{lll} & 5-150 \\ 0 & 150-300 & 0\end{array}$

$300-450$

450-600

$600-821$
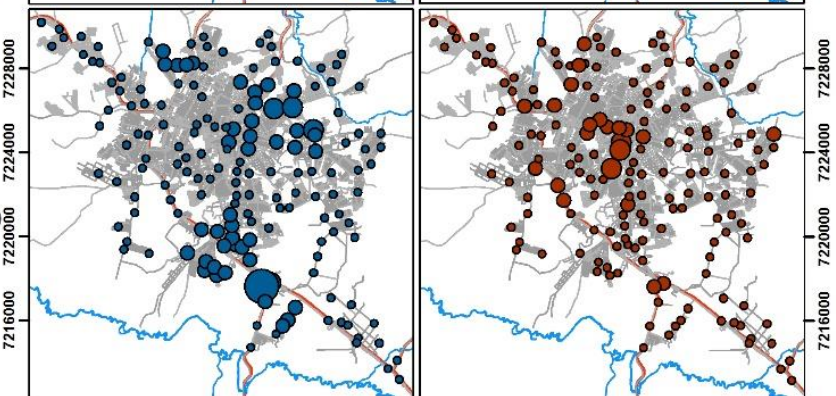

SO2 hourly $\left(\mathrm{ug} / \mathrm{m}^{3}\right)$
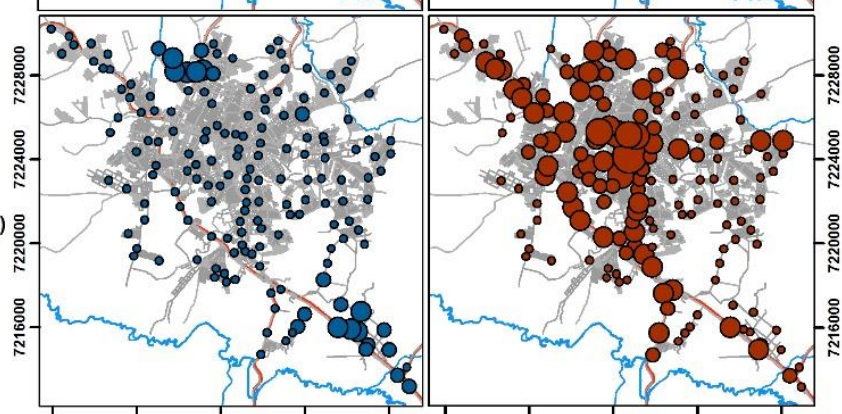

Projection: UTM Zone 22S - Datum: SIRGAS 2000

Fig. 4: Pollutants maximum hourly concentrations and average concentrations for the five-year period obtained by modelling. This method considers stationary and mobile sources separately at each discrete receptor. 
For nitrogen oxides, there is a greater contribution from stationary sources, especially those related to agribusiness and food. The point of highest concentration was located near the emission source. Although there were other fixed emission sources of this pollutant, its concentration at discrete receptors was not significant. Thus, a gradual reduction in NOx concentration is observed with distance from emission sources. For mobile sources, the city's central region registers higher concentrations in the five-year average due to vehicle flow as well as proximity to fixed sources of some regions near highways that cut/surround the city.

Fig. 4 shows two different situations for sulphur dioxide. In the hourly maximums, the largest contribution comes from point sources, with the highest concentrations located near points of emission. In the five-year period average, the highest contribution is from mobile sources with the highest concentrations located at city centre points and along the highways and avenues of intense vehicle flow.

The first two principal components obtained for modelled concentrations and bromeliad occurrence explained $60 \%$ of the data (Fig. 5). In Fig. 5, the circle size indicates the correlation obtained and the colours indicate the variable being correlated or grouped.
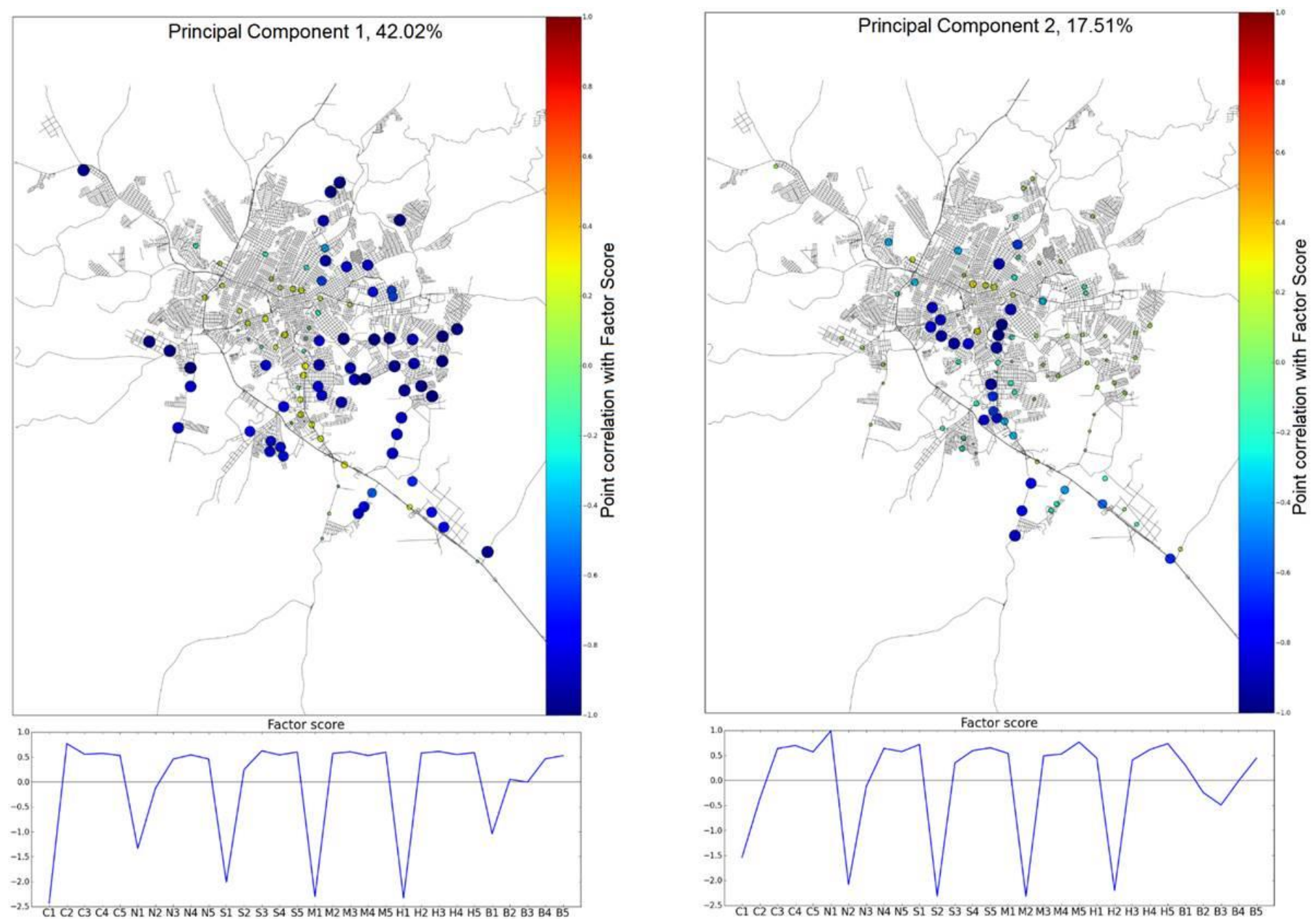

Fig. 5: Results of the first two principal components analysis. In this chart, the variable names have been abbreviated for easy viewing. Letters indicate the variable and numbers indicate the class to which it belongs. For example, $\mathrm{C} 1 \mathrm{has} \mathrm{C}$, referring to the pollutant $\mathrm{CO}$, and 1, the first class analysed, being the one of smaller concentrations. Logically, C5 is the class with the highest CO values. Thus, $\mathrm{C}$ represents $\mathrm{CO}, \mathrm{N}$ represents NOx, S represents $\mathrm{SO}$, M represents $\mathrm{PM}, \mathrm{H}$ represents $\mathrm{HCT}$ and $\mathrm{B}$ represents the infestation index of bromeliads. 
The first principal component explains more than $40 \%$ of the data. The main correlations occurred between the lower classes of pollutants, or those with the lowest concentrations, and the lowest class of bromeliad infestation. These highest correlations are highlighted in the south-central city region in the spatial analysis.

The second principal component accounts for approximately $17 \%$ of the data and together with the first, accounts for almost $60 \%$ of the variance. This component grouped the first class of CO with the second class of pollutants, NOx, SO2, $\mathrm{PM}$ and HCT, and the third class of the bromeliad infestation index.

Using spatial analysis major correlations are observed in the main access to the city centre from the highway in the south and in some points in the western region of the city's urban area. This result indicates a correlation between pollutants and bromeliad infestation in a region with greater vehicular emissions than industrial emissions. This finding is in agreement with the conclusions obtained by Piazzetta [6]; the presence of $T$. recurvata is indicative of air quality change because it is not significantly impacted by the addition of substances to the atmosphere, but occurs in greater abundance in these areas and accumulates substances proportionally.

\section{Conclusion}

To evaluate the correlation between atmospheric pollutants and bromeliad occurrence in electric network structures was compared field data about the bromeliad infestation and the pollutants concentration by atmospheric dispersion modelling. The results present that there is a correlation between atmospheric pollutants and bromeliad infestation in the electric power distribution network. The correlation is more prominent among the lower classes of pollutants, or those with the lowest concentrations, and the lowest bromeliad infestation class.

In addition, results indicate a correlation between pollutants and bromeliad infestation in regions with greater vehicular emissions than industrial emissions in the city of Ponta Grossa, Paraná, Brazil. These regions are in the city centre and along the highways and avenues of greater flow. However, it is not possible to isolate the vehicle contributions from the industrial ones.

\section{Acknowledgements}

The authors would like to thank the Brazilian National Electric Energy Agency (ANEEL) and Copel Distribuição S. A. for funding the research and developing the project that includes this work. They also thank the contributions of the other researchers involved in the project.

\section{References}

[1] M. El-Harbawi, "Air quality modelling, simulation and computational methods: a review," Environmental Reviews, vol. 21, no. 3, pp. 149-179, 2013.

[2] R. Reitz, Bromeliads and the endemic malaria-bromeliad, (in Portuguese), Itajaí, Brazil: Herbário Barbosa Rodrigues, 1983.

[3] J. J. S. Santos, "Study of Tillandsia spp (Bromeliaceae) epiphytes in electric power distribution lines of Curitiba," (in Portuguese), M.S. thesis, Institute of Technology for Development, Curitiba, Brazil, 2014.

[4] A. B. Abril and E. H. Bucher, "A comparison of nutrient sources of the epiphyte Tillandsia capillaris attached to trees and cables in Cordoba, Argentina," J. Arid Environ., vol. 73, no. 3, pp. 393-395, 2009.

[5] S. Wester and G. Zotz, "Growth and survival of Tillandsia flexuosa on electrical cables in Panama," J. Trop. Ecol., vol. 26, no. 1, pp. 123-126, 2010.

[6] K. D. Piazzetta, "Evaluation of potential of Tillandsia recurvata (L.) L., Bromeliaceae, as bioindicator of urban air pollution," M.S. thesis, Federal University of Technology, Paraná, Curitiba, Brazil, 2015.

[7] M. E. Puente and Y. Bashan, "The desert epiphyte Tillandsia recurvata harbours in nitrogen-fixing bacterium Pseudomonas stutzeri," Can. J. Bot., vol. 72, pp. 406-408, 1994.

[8] J. Barrat, "Study reveals hazards of the high-wire life for bromeliads," Bromeliana, vol. 49, no. 7, pp. 1-4, 2012.

[9] D. H. Benzing and J. Sheemann, "Nutritional piracy and host decline: a new perspective on the epiphyte-host relationship," Selbyana, vol. 2, no. 2/3, pp. 133-148, 1978.

[10] F. K. Claver, J. R. Alanis and D. O. Caldis, "Tillandsia spp.: epiphytic weeds of trees and brushes," Forest Ecol. Manag., vol. 6 no. 4, pp. 367-372, 1983. 
[11] E. Schrimpff, "Air pollution patterns in two cities of Colombia, S. A. according to trace substances contented of an epiphyte (Tillandsia recurvata L.)," Water Air Soil Poll., vol. 21, no. 1, pp. 279-315, 1984.

[12] G. M. A. Bermudez, J. H. Rodriguez and M. L. Pignata, "Comparison of the air pollution biomonitoring ability of three Tillandsia species and the lichen Ramalina celastri in Angentina," Environ. Res., vol. 109, no. 1, pp. 6-14, 2009.

[13] A. Z. Garcia, C. M. Coyotzin, A. R. Amaro, D. L. Veneroni, L. C. Martínez and S. G. Iglesias, "Distribution and sources of bioaccumulative air pollutants at Mezquital Valley, Mexico, as reflected by the atmospheric plan Tillandsia recurvata L.," Atmos. Chem. Phys., vol. 9, no. 17, pp. 6479-6494, 2009.

[14] M. L. Pignata, G. L. Gudino, E. D. Wannaz, R. R. Plá, C. M. González, H. A. Carreras and L. Orellana, "Atmospheric quality and distribution of heavy metals in Argentina employing Tillandsia capillaris as a biomonitor," Environ. Pollut., vol. 120, no. 1, pp. 59-68, 2002.

[15] E. D. Wannaz, H. A. Carreras, C. A. Pérez and M. L. Pignata, "Assessment of heavy metal accumulation in two species of Tillandsia in relation to atmospheric emission sources in Argentina," Sci. Total Environ., vol, 361, no. 13, pp. 267-278, 2006.

[16] H. A. Carreras, E. D. Wannaz and M. L. Pignata, "Assessment of human health risk related to metals by the use of biomonitors in the province of Córdoba, Argentina," Environ. Pollut., vol. 157, no. 1, pp. 117-122, 2009.

[17] J. H. Rodriguez, S. B. Weller, E. D. Wannaz, A. Klumpp and M. L. Pignata, "Air quality biomonitoring in agricultural areas nearby to urban and industrial emission sources in Córdoba province, Argentina, employing the bioindicator Tillandsia capillaris," Ecol. Indic., vol. 11, no. 6, pp. 1673-1680, 2011.

[18] E. D. Wannaz, H. A. Carreras, G. A. Abril and M. L. Pignata, "Maximum values of $\mathrm{Ni}^{2+}, \mathrm{Cu}^{2+}, \mathrm{Pb}^{2+}$ and $\mathrm{Zn}^{2+}$ in the biomonitor Tillandsia capillaris (Bromeliaceae): Relationship with cell membrane damage," Environ. Exp. Bot., vol. 74, pp. 296-301, 2011.

[19] E. D. Wannaz, H. A. Carreras, J. H. Rodriguez and M. L. Pignata, "Use of biomonitors for the identification of heavy metals emission sources," Ecol. Indic., vol. 20, pp. 163-169, 2012.

[20] S. Goix, E. Resongles, D. Point, P. Oliva, J. L. Duprey, E. Galvez, L. Ugarte, C. Huayta, J. Prunier, C. Zouiten and J. Gardon, "Transplantation of epiphytic bioaccumulators (Tillandsia capillaris) for high special resolution biomonitoring of trace elements and point sources deconvolution in a complex mining/smelting urban context," Atmos. Environ., vol. 80, pp. 330-341, 2013.

[21] M. A. Martínez-Carrillo, C. Solís, E. Andrade, K. Isaac-Olivé, M. Rocha, G. Murillo, R. I. Beltrán-Hernández and C. A. Lucho-Constanyino, "PIXE analysis of Tillandsia usneoides for air pollution studies at an industrial zone in Central Mexico," Microchem J., vol. 96, no. 2, pp. 386-390, 2010.

[22] C. A. Nogueira, "Air pollution evaluation of metals in the metropolitan region of São Paulo using the bromeliad Tillandsia L. usneoides as biomonitor," Ph.D. dissertation, Institute of Nuclear and Energetics' Researches, University of São Paulo, São Paulo, Brazil, 2006.

[23] A. F. Godoi, R. H. M. Godoi, R. Azevedo and L. T. Maranho, "Pollution and the vegetation density: BTEX in some public areas of Curitiba-PR, Brazil," Química Nova, vol. 33, no. 4, pp. 827-833, 2010.

[24] A. M. G. Figueiredo, C. A. Nogueira, M. Saiki, F. M. Milian and M. Domingos, "Assessment of atmospheric metallic pollution in the metropolitan region of São Paulo, Brazil, employing Tillandsia usneoides L. as biomonitor," Environ. Pollut., vol. 145, no. 1, pp. 279-292, 2007.

[25] N. A. Vianna, D. Gonçalves, F. Brandão, R. P. Barros, G. M. A. Filho, R. O. Meire, J. P. M. Torres, O. Malm, A. D. O. Júnior and L. R. Andrade, "Assessment of heavy metals in the particulate matter of two Brazilian metropolitan areas by using Tillandsia usneoides as atmospheric biomonitor," Environ. Sci. Pollut. R., vol. 18, no. 3, pp. 416-427, 2011. 